\title{
Editorial
}

Päivi Soppela*

\section{Preface to the Special Issue on the 10th Circumpolar Agriculture Conference 2019}

https://doi.org/10.1515/opag-2020-0091

received December 10, 2020; accepted December 18, 2020

The 10th Circumpolar Agriculture Conference was held from 13 to 15 March 2019 in Rovaniemi, Finland. The conference was organized within the framework of CAA (Circumpolar Agricultural Association) and offered a forum for discussions to researchers, policy-makers and practitioners from all over the Arctic. In total, 170 participants from 12 different countries attended the conference. Participants came from Canada, Denmark, Greenland, Finland, Faroe Islands, Iceland, Norway, Russia, Sweden, the United States (mainly from Alaska) and from several other countries.

The goal of the conference was to address new thinking and a bottom-up approach to local agriculture, locally produced food and rural development in northern areas. The role of agriculture in different parts of the Arctic region was discussed, as well as its topical challenges and opportunities, including the implications of climate change and food security.

Agriculture has a very different meaning in the Arctic than in the southern areas. It is remarkably diverse in different parts of the circumpolar Arctic depending on the local environment, conditions and resources. It takes various forms, extending from animal husbandry and cultivation of locally manageable crops and plants, to nature-based livelihoods and the utilization of natural products of forests and waters. Reindeer herding, hunting, gathering and fishing have a particular role in Arctic food systems as they also have as a way of life and livelihoods among indigenous and local people.

What is common all over the Arctic are the challenges caused by accelerating climate change, land use and globalization of food production. To respond and adapt to these challenges we need timely research, policies and practices. What we also need is to look for the

\footnotetext{
* Corresponding author: Päivi Soppela, 10th Circumpolar Agriculture Conference, Chair, Arctic Centre, University of Lapland, Rovaniemi, Finland, e-mail: paivi.soppela@ulapland.fi
}

opportunities and means for sustainable local food production. The more we can locally produce food in our own areas, the less dependent we are on external resources and the more resilient our rural regions and communities are.

In recent years, local foods, natural products and small-scale production have seen a rising trend worldwide. In this conference, the potentials of local small-scale production and the natural products sector in the Arctic were emphasized by giving a voice to both researchers and producers. The conference specifically addressed the high quality of Arctic foods, their local profitability and business opportunities by organizing the Arctic Deli market, and an excursion in North-East Lapland to meet producers.

Food security was also one of the important focuses of the program. A year ago we had not yet experienced the covid-19 pandemic that is now affecting all regions worldwide, including the Arctic. Now that we are in the middle of it, there is a higher pressure on food security and local food production than ever, regarding both their practice and research.

In total, 99 papers and posters were presented in the conference. They featured best practices and local solutions in the utilization of animal and plant resources, northern adapted breeds, reindeer herding, small-scale farming, forest foods, among others. The papers represented different fields of research, bringing together both natural and social scientists to learn from each other and find a common ground.

This Special Issue is based on 11 participants' fulllength papers submitted and peer-reviewed after the Conference. The wide scope of circumpolar agriculture and its regional and local characteristics are reflected in the papers. They highlight local conditions and solutions but also the high importance of Arctic cooperation and exchange of knowledge across borders in order to respond to joint challenges and bring forward opportunities such as digitalization.

The Circumpolar Agriculture Conference was one of the events organized during Finland's Chairmanship period of the Arctic Council. The local organizer of the conference was the Arctic Centre at the University of 
Lapland in cooperation with the Natural Resources Institute Finland and several local institutions in Lapland. Further information: CAC2019 homepage.

We would like to thank all the authors of this Issue for their valuable contribution.

We also thank the participants, organizers and supporters of the 10th CAC who made this conference a great success.

Special Issue Guest Editors:
Päivi Soppela: 10th Circumpolar Agriculture Conference, Chair, Arctic Centre, University of Lapland, Rovaniemi, Finland, e-mail: paivi.soppela@ulapland.fi

David Natcher: Department of Agriculture and Resource Economics, University of Saskatchewan, Saskatchewan, Canada

Torfi Johannesson: Senior Adviser on Land and Forestry, Nordic Council of Ministers, Copenhagen, Denmark. 